\title{
Anthelmintic treatments in pregnant or lactating sows for control of sow and piglet parasites. Their influence on piglet performances
}

\author{
J. P. RAYNAUD et A. BOUCHET \\ Station de Recherche et Développement vétérinaive et Nutrition animale, \\ Pfizer International, 37400 Amboise
}

\begin{abstract}
A study was carried out on the effectiveness of methods used to prevent piglet parasitism by intervention on the pregnant or lactating sow. This intervention would eliminate any systematic treatment of piglets up to weaning and would assure the prevention of the infection.

In 13 farms including 92 sows from 29 blocks (3. I sows in each), 850 ncwborn piglets and 706 weaned piglets were controlled. I 86 weaned piglets ( 2 in each litter) were sacrificed for total worm count. The anthelmintic (Morantel tartrate or Pyrantel tartrate) was given twice in the feed of one meal 18 days and 3 days before farrowing ( ${ }^{\circ} \mathrm{I}$ ) or for $\mathrm{I}^{\circ}$ days prior to farrowing $\left(\mathrm{n}^{\circ} 2\right)$, or twice in the feed of onc meal, 2 days before and $10-2$ I days after farrowing $\left(n^{0} 3\right)$.

A very good control of gastro intestinal parasitism in sows, improving also piglet performances by decreasing or suppressing their parasitic contamination was achieved by a continuous administration in the diet of a sufficient amount of Morantel for so days before farrowing (above $2.5 \mathrm{mg} / \mathrm{kg}$ live weight $/ \mathrm{day}=25 \mathrm{mg} / \mathrm{kg}$ live weight on the whole) or in 2 Pyrantel or Morantel treatments ( $12.5 \mathrm{mg} / \mathrm{kg}$ live weight, $25 \mathrm{mg} / \mathrm{kg}$ live weight on the whole) at intervals of 2 weeks before farrowing (treatments $\mathrm{n}^{0} \mathrm{I}$ and $\mathrm{n}^{\circ} 2$ ). Equivalent results were obtaincd with 2 Morantel treatments, one before and the other after farrowing (treatment 3 ).
\end{abstract}

\section{V. - FEeDING}

\section{Influence of protein restriction from $25 \mathrm{~kg}$ live weight on the reproductive performances of the gilt}

\author{
P. H. DUÉE \\ Station de Recherches sur l'Elevage des Porcs, \\ I.N.R.A.-C.N.R.Z., 78350 Jouy-en-Josas (Fivance)
}

An cxperiment was conducted on $7^{\circ}$ Large White gilts in order to determine the effects of protein and lysine deficiency during the whole or part of the growing period on the onset of puberty, the ovulation rate at lst ocstrus and the reproductive performances at 30 days of pregnancy on the one hand and at farrowing, on the other.

From $25 \mathrm{~kg}$ live weight and until puberty, the animals were distributed into 3 groups fed according to a feeding schedule either a low protein diet ( 1.5 per cent) supplemented or not with lysine (total content of the diets: group $1: 0.42$ per cent; group 2: 0.62 per cent) or a high protein diet (group 3: 17.5 per cent crude protein, 0.86 per cent lysine).

At puberty, the animals which were mated were subjected to the same feeding level $(2.2 \mathrm{~kg} / \mathrm{day})$ and received the diet of group I either during 30 days of pregnancy (one half of the animals) or during whole pregnancy (the other half of the animals).

Protein restriction delayed the growth of the animals (group I), mainly from 25 to $60 \mathrm{~kg}$ live weight. However, L. Lysine supplementation (group 2) improved the daily mean gain. The supplementary supply of protein had only a favourable effect on growth performance during the first part of the period (from 25 to $65 \mathrm{~kg}$ live weight). As regards the age at puberty, no 
significant difference was observed between groups (group I: 263 days; group 2: 263 days; group 3: 255 days).

As compared with the other groups, the weight at puberty of gilts in group 1 was significantly lower and so was the ovulation rate (group I: I0,4; group 2: 12,6 ; group 3: I 2.6). This lowering of the ovulation rate affected the litter size at 3 o days (group $1: 8.5$; group $2: 9.3 ;$ group 3 : 10.7), but not a.t farrowing (group 1: 8.5 ; group 2: 8.5 ; group 3 : 8.5).

\title{
Use of horse-bean in pregnant gilt diets
}

\author{
M. ÉTIENNE \\ Station de Recherches sur l'Elevage des Porcs, \\ I.N.R.A.-C.N.R.Z., 78350 Jouy-en-Josas (France)
}

In the present experiment, 54 nulliparous Large White gilts were used to study the effects of a total substitution of soya-bean meal for whole horse-bean in the gestation diet on the survival and development of the embryos. The animals were distributed into three groups. Groups I and 2 received a diet containing 8 per cent soya-bean meal and 15 per cent "Ascott" horse-bean, respectively ensuring the same protein supply (12.3 per cent crude protein). The diet of the gilts of group 3 included 25 per cent horse-bean in order to measure the eventual effects of a higher supply of this feedstuff. Between mating at puberty (255 days of age, I $7 \mathrm{~kg}$ ) and slaughter at 105 days of pregnancy, the gilts received daily $2.2 \mathrm{~kg}$ of their respective diets.

The proportion of non-fertilized gilts was the same in the three groups $(24 \%)$. No difference appeared between the fenules with respect to weight gain (55 kg), ovulation rate (13.5), mean weight of corpora lutea $(0.53 \mathrm{~g})$ and total weight of ovaries ( $13.12 \mathrm{~g})$. This was also the case for the number of normal $(9.4 \mathrm{I})$ or abnormal foetuses $(0.37)$ per litter and total embryonic mortality (29.8 per cent). However, the individual weight was lower for foetuses $(923,825$ and $854 \mathrm{~g}$, respectively in groups 1,2 and 3$)$ and placentas $(212,184$ and $194 \mathrm{~g})$ of the gilts fed with horsebean (groups 2 and 3 ). This suggests that the embryonic mortality might be increased in these animals in the case of a ligher prolificacy, since the resulting greater competition among foetuses would more affect less vigourous individuals. However that may be, the horse-bean factors responsible for reduction in the weight of foetuses have not yet been determined.

\section{Use of a potato protein concentrate in the diet of piglets weaned at 10 or at 21 days}

\author{
B. SÈVE
}

Station de Recherches sur l'Elevage des Porcs, I.N.R.A.-C.N.R.Z., 78350 Jouy-en-Josas (France)

\footnotetext{
The nutritive value of a potato protein concentrate (CPDT $=$ PPC: 83.5 per cent of $N \times 6,25$ 6.3 per cent lysine/dry matter) was estimated during two experiments each including 6 piglets weaned at io or at $2 \mathrm{I}$ days.

In the first experiment, the piglets primaily received lst age diets containing 25 per cent crude protein out of which 50 per cent was skim-milk. The other fraction ( $5^{\circ}$ per cent) was constituted of dissolved fish (CPSP $=\mathrm{DFPC}$ ) in groups I (control) and 2 ; in groups 3 and 4 , this fraction was composed of 25 per cent DFPC and 25 per cent PPC, finely ground or not, in group 5. 50 per
} 